\title{
Gas exchange, Chlorophyll Fluorescence and Pigments of Noni (Morinda citrifolia L.) under Salt Stress
}

\author{
A. M. W. Cova ${ }^{1}$, André D. Azevedo Neto ${ }^{1,2}$, Hans R. Gheyi ${ }^{1}$, Rogério F. Ribas ${ }^{1}$, Leandra B. de Oliveira ${ }^{1}$ \\ \& Renata V. Menezes ${ }^{1}$ \\ ${ }^{1}$ Centro de Ciências Agrárias, Ambientais e Biológicas, Universidade Federal do Recôncavo da Bahia, Cruz das \\ Almas, Brazil \\ ${ }^{2}$ Centro de Ciências Exatas e Tecnológicas, Universidade Federal do Recôncavo da Bahia, Cruz das Almas, \\ Brazil \\ Correspondence: André D. Azevedo Neto, Centro de Ciências Exatas e Tecnológicas, Universidade Federal do \\ Recôncavo da Bahia, R. Rui Barbosa, 710, Centro, Cruz das Almas, BA., CEP: 44380-000, Brazil. Tel: \\ 55-75-3621-9362. E-mail: andre@ufrb.edu.br
}

Received: November 19, 2017

Accepted: December 20, 2017 Online Published: January 15, 2018

doi:10.5539/jas.v10n2p318

URL: https://doi.org/10.5539/jas.v10n2p318

The research is financed by Coordenação de Aperfeiçoamento de Pessoal de Nivel Superior (CAPES), Universidade Federal do Recôncavo da Bahia (UFRB) and the Programa de Pós-Graduação em Engenharia Agricola of the UFRB.

\begin{abstract}
Noni is a fruit crop well adapted to different soil and climatic conditions. Aiming to evaluate the physiological responses to salinity, noni seedlings were grown in two levels of $\mathrm{NaCl}(0$ and $100 \mathrm{mM})$ in nutrient solution and the effects of salt stress on gas exchange, chlorophyll $a$ fluorescence, photosynthetic pigments, relative water content and membrane integrity were assessed after 1,10,20,30 and 40 days of salt stress. The experimental design was a completely randomized in $2 \times 5$ factorial arrangement with four replications. Salinity did not affect the intrinsic efficiency of water use, but reduced net assimilation of $\mathrm{CO}_{2}$, stomatal conductance, transpiration, carboxylation efficiency and contents of chlorophyll $a, b$, and total carotenoids. Salinity caused no major changes in chlorophyll fluorescence, however the stressed plants showed a decrease in photoprotection capacity by the cycle of xanthophylls. Salinity did not affect the water status of the leaves, but damages to the integrity of the membranes were observed due to duration of salt exposure. The data indicate that noni presents stomatal closure as a mechanism of salinity tolerance, reducing water loss by transpiration and maintaining the water status.
\end{abstract}

Keywords: photosynthesis, stomatal conductance, energy dissipation, membrane integrity

\section{Introduction}

The increase in salinity of the soil solution beyond the tolerance capacity of the plants is an obstacle to agricultural production, particularily in irrigated soils of arid and semi-arid regions. In Brazil, the semi-arid region occupies an area of $969,589.4 \mathrm{~km}^{2}$, located mainly in the Northeast part of the country (Brazil, 2007). In these areas, the scarce availability of water associated with use of brackish groundwater in irrigation, and climatic conditions, decreases the agricultural production, which is one of the main environmental obstacles to agricultural development in the region.

Crops in arid and semi-arid regions are often irrigated with poor quality water at certain time of the year, since in most areas it is the only source of water. However, across most of the countries in the world, it has been successfully used with adoption of appropriate management practices of soil, water and the use of plants tolerant to salinity (Bezerra, Lacerda, Hernandez, Silva, \& Gheyi, 2010).

The salinity may decrease the absorption of water by plants, and provoke unbalanced nutrition, as well as modify the metabolic process and decrease the photosynthetic efficiency of crops (Munns \& Tester, 2008; Iqbal, Umar, N. Khan, \& M. Khan, 2014). Thus, plants need to use physiological and biochemical mechanisms to face the 
osmotic and specific ion effects of salts. Therefore, it is necessary to understand the mechanisms of tolerance of plant to salinity for economical agricultural production.

The study of physiological variables such as stomatal conductance and chlorophyll $a$ fluorescence are important to explain the osmotic effects and water conditions imposed by salinity on photosynthetic efficiency of plants. In this context, some gas exchange and chlorophyll $a$ fluorescence studies have been used as a nondestructive method for evaluating the plant's tolerance to salinity (Silva, Ribeiro, Ferreira-Silva, Viégas, \& Silveira, 2011; Azevedo Neto, Perreira, Costa, \& Santos, 2011; Silva et al., 2014). These variables are of fast and non-invasive determination, which allow to monitor the development of the plant, providing qualitative and quantitative information on the physiological conditions of photosynthetic processes (Silva et al., 2011; Kalaji et al., 2014).

The chlorophyll $a$ fluorescence determines the state of energy distribution in the thylakoid membrane, the quantum efficiency of photosystem II (PSII) and the extent of photoinhibition (H. Wang, F. Wang, G. Wang, \& Majourhat, 2007). Thus, the qualitative and quantitative information about the photosynthetic processes in chloroplasts show the functioning of the photosynthetic apparatus under different internal and external conditions (Roháček \& Barták, 1999).

Silva et al. (2011) reported that the salinity strongly reduces the gas exchanges and the photochemical activity in Jatropha curcura, caused by ionic stress. Therefore, evaluations of exchanges and chlorophyll $a$ fluorescence can be utilized as tools to diagnose the integrity of photosynthetic apparatus under adverse environmental conditions (Gonçalves et al., 2010).

Morinda citrifolia Linn, popularly known as noni, belongs to Rubiaceae family and is a medicinal plant used over 2000 years by the Polynesians (Chan-Blanco et al., 2006). The leaves and especially the fruits are consumed in different ways by many communities around the world due to the effects related to antioxidant, anti-inflammatory, analgesic, immunomodulatory, antibacterial, antitumor activity, sources of vitamins, among others (Chan-Blanco et al., 2006; Costa, Oliveira, Silva, Macini-Filho, \& Lima, 2013).

Noni cultivation can be a viable alternative for the arid and semiarid regions. The plant acclimatizes to diverse environmental conditions (Nelson \& Elevitch, 2006), though some studies have shown that irrigation with saline water reduces its growth (Souto et al., 2015a; Souto, Cavalcante, Lima Neto, Mesquita, \& Santos, 2016).

Considering the medicinal importance of noni, its adaptive capacity, and the lack of information on its growth in saline environment, this study aimed to evaluate the gas exchange, the chlorophyll $a$ fluorescene, and the pigment contents in noni plants under stress, for a better understanding of the tolerance mechanisms to salt stress of this species.

\section{Materials and Methods}

\subsection{Growth and Treatment Conditions}

The experiment was carried out in a greenhouse, in a completely randomized design, by using the factorial scheme of five harvest times versus two $\mathrm{NaCl}$ levels of salinity in nutrient solution, with four replicates. The mean values of temperature, air relative humidity, and photosynthetic active radiation (at noon) were $25^{\circ} \mathrm{C}, 81 \%$ and $1200 \mu \mathrm{mol} \mathrm{m} \mathrm{m}^{-1}$, respectively.

Noni seedlings three months old and with four pairs of leaves were selected. Seedlings were transferred to containers with $12 \mathrm{~L}$ of Furlani (1998) nutrient solution, in a Floating hydroponic system. Noni seedlings remained in nutrient solution for four days for acclimation. After this period, the seedlings were submitted to the respective salt treatments (nutrient solution without $\mathrm{NaCl}$ - control or nutrient solution with $100 \mathrm{mM} \mathrm{NaCl}-\mathrm{salt}$ stress). Sodium chloride was gradually added $\left(25 \mathrm{mM} \mathrm{day}^{-1}\right)$, to avoid osmotic shock. The volume of the solutions was completed daily with water and the renewal was performed weekly. The $\mathrm{pH}$ was maintained at $6.0 \pm 0.2$ by adding $\mathrm{NaOH}$ or $\mathrm{HCl}$. The system was maintained under intermittent aeration of 15 minutes every hour, using an air compressor coupled to a timer.

Plants from each treatment were harvested at 1, 10, 20, 30 and 40 days after the end of salt additions and shoot dry mass (SDM) was obtained after drying in an oven at $65^{\circ} \mathrm{C}$ for $72 \mathrm{~h}$.

\subsection{Gas Exchange}

Assimilation rate of $\mathrm{CO}_{2}(A)$, stomatal conductance $\left(g_{s}\right)$, transpiration $(E)$, water use efficiency (WUE), carboxylation efficiency $(A / \mathrm{Ci})$, and leaf temperature $\left(T_{f}\right)$ were obtained with a LI-6400XT portable gas exchange measuring system (LI-COR Biosciences Inc., Lincoln, Nebraska, USA) containing a source of blue/red light. The measurements were performed every 10 days, from 8:00 a.m. to 10:00 a.m., under artificial saturating 
light at $1000 \mu \mathrm{mol}$ photons $\mathrm{m}^{-2} \mathrm{~s}^{-1}$. Ten observations per leaf (one at every 12 seconds) were performed, and the average was considered as a measure.

\subsection{Photochemical Efficiency}

The chlorophyll $a$ fluorescence measurements were performed at the same time and in the same leaves used for gas exchange evaluations using a OS5p modulated portable fluorometer (Opti-Sciences, Hudson, New Hampshire, USA). Minimum fluorescence $\left(\mathrm{F}_{0}\right)$, maximum fluorescence $\left(\mathrm{F}_{\mathrm{m}}\right)$, the potential $\left(\mathrm{F}_{\mathrm{v}} / \mathrm{F}_{\mathrm{m}}\right)$, and effective ( $\left.\mathrm{Y}_{\mathrm{II}}\right)$ quantum yields of photosystem II (PSII) were determined. The quantum yield of regulated ( $\left.\mathrm{Y}_{\mathrm{NPQ}}\right)$ and non-regulated $\left(\mathrm{Y}_{\mathrm{NO}}\right)$ quenching of the absorbed energy in PSII were calculated according to Kramer, Johnson, Kiirats, and Edwards, (2004), and Klughammer and Schreiber (2008).

\subsection{Photosynthetic Pigments}

The chlorophyll $a(\mathrm{Chl} a)$, chlorophyll $b(\mathrm{Chl} b)$, and carotenoids (Car) contents were determined by spectrophotometry at $664.1,648.6$ and $470 \mathrm{~nm}$, in ethanol (95\%) extract, according to the methodology described by Lichtenthaler and Buschmann (2001), by using the following equations:

$$
\begin{gathered}
\text { CHLa }\left(\mu \mathrm{g} \mathrm{mL}{ }^{-1}\right)=13.36 \times \mathrm{A}_{664}-5.19 \times \mathrm{A}_{649} \\
\mathrm{CHL} b\left(\mu \mathrm{g} \mathrm{mL} \mathrm{mL}^{-1}\right)=27.43 \times \mathrm{A}_{649}-8.12 \times \mathrm{A}_{664} \\
\operatorname{Car}\left(\mu \mathrm{g} \mathrm{mL}{ }^{-1}\right)=\left(1000 \times \mathrm{A}_{470}-2.13 \times \mathrm{CHL} a-97.64 \times \mathrm{CHL} b\right) / 209
\end{gathered}
$$

The total chlorophyll content (Chl tot), and the $\mathrm{Chl} a / \mathrm{Chl} b$ and $\mathrm{Chl}$ tot/Car ratios were calculated from Chl $a$ and Chl $b$ data.

\subsection{Integrity of Cell Membranes and Relative Water Content}

The percentage of absolute integrity (PAI) of cell membranes and the relative water content (RWC) were estimated on the same leaves used for determination of pigment contents. Ten leaf discs of $7 \mathrm{~mm}$ of diameter were used for both analyses. PAI and RWC were determined according to methodologies described by Pimentel, Sarr, Diouf, Abboud, and Roy-Maculey (2002), and Barrs and Weatherley (1962), respectively.

\subsection{Statistical Analysis}

Data were compared through their means and respective standard deviations, according to Snedecor (1956).

\section{Results and discussion}

\subsection{Shoot Dry Mass Production}

In both salt treatments, the shoot dry mass of the noni plants increased during the experimental period (Figure 1). However, at the end of the experimental period, in $100 \mathrm{mM} \mathrm{NaCl}$ the production of shoot dry mass was reduced by $30 \%$ when compared with control.

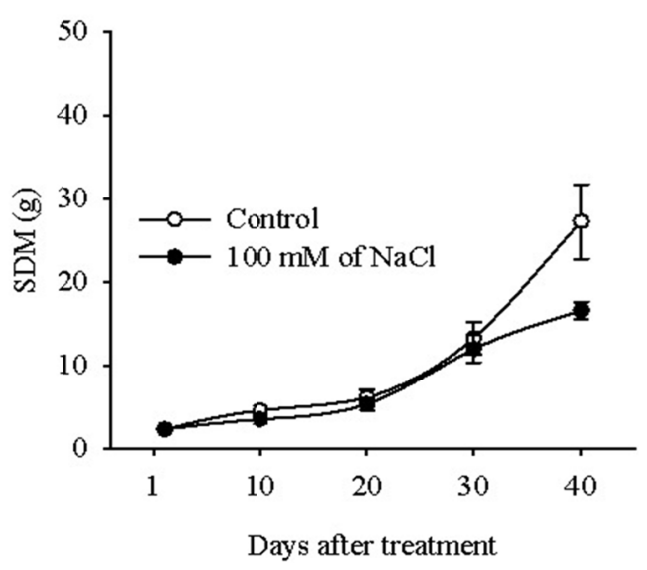

Figure 1. Shoot dry mass (SDM) of noni plants grown during 40 days in hydroponic system, in absence - control (०) or presence of $100 \mathrm{mM} \mathrm{NaCl}(\bullet)$ on nutrient solution. The values indicate the average of four replicates and the vertical lines represent respective standard deviations 
The salt stress imposition on noni plants affected the shoot growth and the gas exchange with increasing days of stress. These data corroborate with Souza, Lacerda, Amorim, and Menezes (2014), who also observed inhibition of shoot dry mass production of noni plants irrigated with saline water up to $6.0 \mathrm{dS} \mathrm{m}^{-1}$. Shoot growth and gas exchange in Ricinus communis were also reduced by $\mathrm{NaCl}$ addition in nutrient solution (Rodrigues et al., 2014). These authors attributed these reductions to stomatal limitation and the accumulation of ions $\mathrm{Na}^{+}$and $\mathrm{Cl}^{-}$.

\subsection{Gas Exchange}

Salinity decreased $A, g_{s}$, and $E$ and increased $T_{f}$. Significant changes were not observed in $W U E$ and $A / C i$ as a result of salt stress (Figure 2). Thus, after 30 and 40 days, reductions of 34 and $29 \%$, respectively were observed in the $A$ of stressed plants as compared to the control ones (Figure 2A). Salinity reduced $g_{s}$ from 10 days onwards (Figure 2B) and $E$ from 20 days (Figure 2C) however, at the end of experimental period, the reduction in $g_{s}(53 \%)$ was more pronounced than in $E(30 \%)$. The $T_{f}$ in the stress treatment was about $1.61{ }^{\circ} \mathrm{C}$ higher than the control during experimental period (Figure 2F). It was also observed that in both treatments, the higher values of $T_{f}$ were observed at the $1^{\text {st }}$ and $30^{\text {th }}$ day.

The salt-induced reduction in photosynthetic rates have been related to stomatal and non-stomatal limitations (Bezerra, Lacerda, Prisco, \& Gomes Filho, 2005; Praxedes, Lacerda, Damatta, Prisco, \& Gomes-Filho, 2010). This study showed that the reduction in $A$ seems to be more associated with stomatal limitation than other factors. The observation that $g s$ was the most sensitive variable to salt stress, and that $A / \mathrm{Ci}$ was not affected by salinity corroborates this hypothesis.

In stressed plants, the lower water availability induced by salinity, reduced the stomatal opening, the water loss by transpiration, and increased the leaf temperature. According to Taiz and Zeiger (2013), the heat is dissipated in the leaves by evaporative cooling during transpiration. Thus, the decrease in $E$ due to stomatal closure raises $T_{f}$, as reported in other plant species (lettuce - Viana, Fernandes, Gheyi, Soares, \& Carneiro, 2004; sugarcane Silva, Jifon, Santos, Jadoski, \& Silva, 2013). In turn, the increase of $T_{f}$ can decrease the $A$ by thermal effects in carboxylation efficiency (Machado, Schmidt, Medina, \& Ribeiro, 2005). However, it is important to highlight that the reductions in $g s$ and $E$ have been reported as tolerance mechanisms to salinity by decreasing the water consumption, and the salt accumulation in the shoot (Silva et al., 2014; Rodrigues et al., 2014).
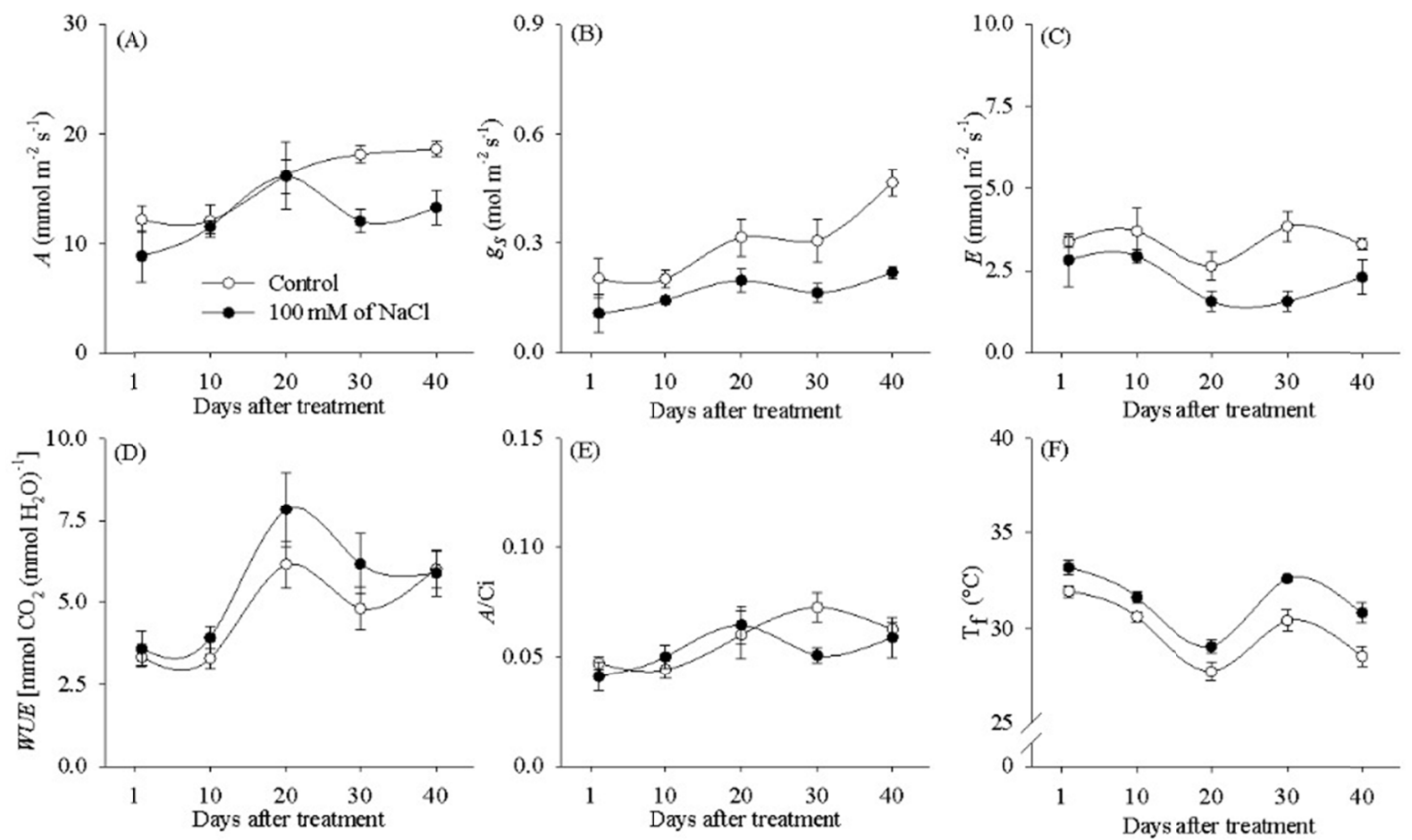

Figure 2. Assimilation rate of $\mathrm{CO}_{2}-A(\mathrm{~A})$, stomatal conductance $-g s(\mathrm{~B})$, transpiration $-E(\mathrm{C})$, water use efficiency $-W U E(\mathrm{D})$, carboxylation efficiency $-A / C i(\mathrm{E})$, and leaf temperature $-T_{f}(\mathrm{~F})$ of noni plants grown for 40 days in hydroponic system, in absence - control ( $($ ) or presence of $100 \mathrm{mM}$ of $\mathrm{NaCl}(\bullet)$ on nutrient solution. The values indicate the average of four replicates and the vertical lines represent respective standard deviations 


\subsection{Chlorophyll a Fluorescence}

The chlorophyll $a$ fluorescence is shown in Figure 3. Salinity did not significantly change the potential quantum yield of PSII $\left(\mathrm{F}_{\mathrm{v}} / \mathrm{F}_{\mathrm{m}}\right)$, the initial fluorescence $\left(\mathrm{F}_{0}\right)$ and maximum fluorescence $\left(\mathrm{F}_{\mathrm{m}}\right)$ during the evaluation period (Figures 3A, 3B and 3C). This figure also shows that the values of $F_{v} / F_{m}$ in plants of both treatments were 0.71 and 0.70 at the $1^{\text {st }}$ and $30^{\text {th }}$ day, respectively.

Chlorophyll fluorescence parameters were not substantially changed by salt stress. However, the values of $F_{v} / F_{m}$ on the first and thirty days were less than 0.725 which according to Critchley (1998), can be an indicative of photoinhibition. These changes probably occurred by the increase of $T_{f}$, which can affect the photosynthetic mechanisms (Peña-Olmos \& Casierra-Posada, 2013). The observation that the lower values of $F_{\mathrm{v}} / F_{\mathrm{m}}$ occurred concomitantly with the higher values of $T_{f}$ corroborates this hypothesis.

The salinity increased by $21 \%$ the effective quantum yield of PSII ( $\mathrm{Y}_{\text {II }}$ ) at 30 days after treatment (Figure 3D), and the quantum yield of non-regulated quenching $\left(\mathrm{Y}_{\mathrm{NO}}\right)$ by 35 and $15 \%$ at 30 and 40 days after treatment, respectively (Figure $3 \mathrm{E}$ ). On the other hand salinity reduced the quantum yield of regulated quenching $\left(\mathrm{Y}_{\mathrm{NPQ}}\right)$ by 16 and $14 \%$ at $30^{\text {th }}$ and $40^{\text {th }}$ day, respectively (Figure $3 \mathrm{~F}$ ).

In contrast to that observed for chlorophyll $a$ fluorescence, the photochemical quenching was changed by salt stress. The salinity increased $Y_{\text {II }}$ at 30 days after treatment, contrary to results observed by Azevedo Neto et al. (2011) in different maize genotypes under salt stress. $Y_{I I}$ is an important parameter because reflects the capacity of plants to convert the photon energy into chemical energy (Klughammer \& Schreiber, 2008), i.e., the proportion of energy used in the NADPH and ATP production. However, in high irradiation conditions may occur an increase of $T_{f}$ and saturation of the reaction centers (Peña-Olmos \& Casierra-Posada, 2013). In this case, when the amount of absorbed energy is higher than that required to photosynthesis, occurs the saturation of photochemical process, resulting in a low photoassimilatory capacity (Taiz \& Zeiger, 2013). Thus, the results show that salt-stressed noni plants presented a higher conversion of light energy into chemical energy compared to control plants. However, the increase of $\mathrm{Y}_{\mathrm{II}}$ was not reflected in the photosynthetic rate.
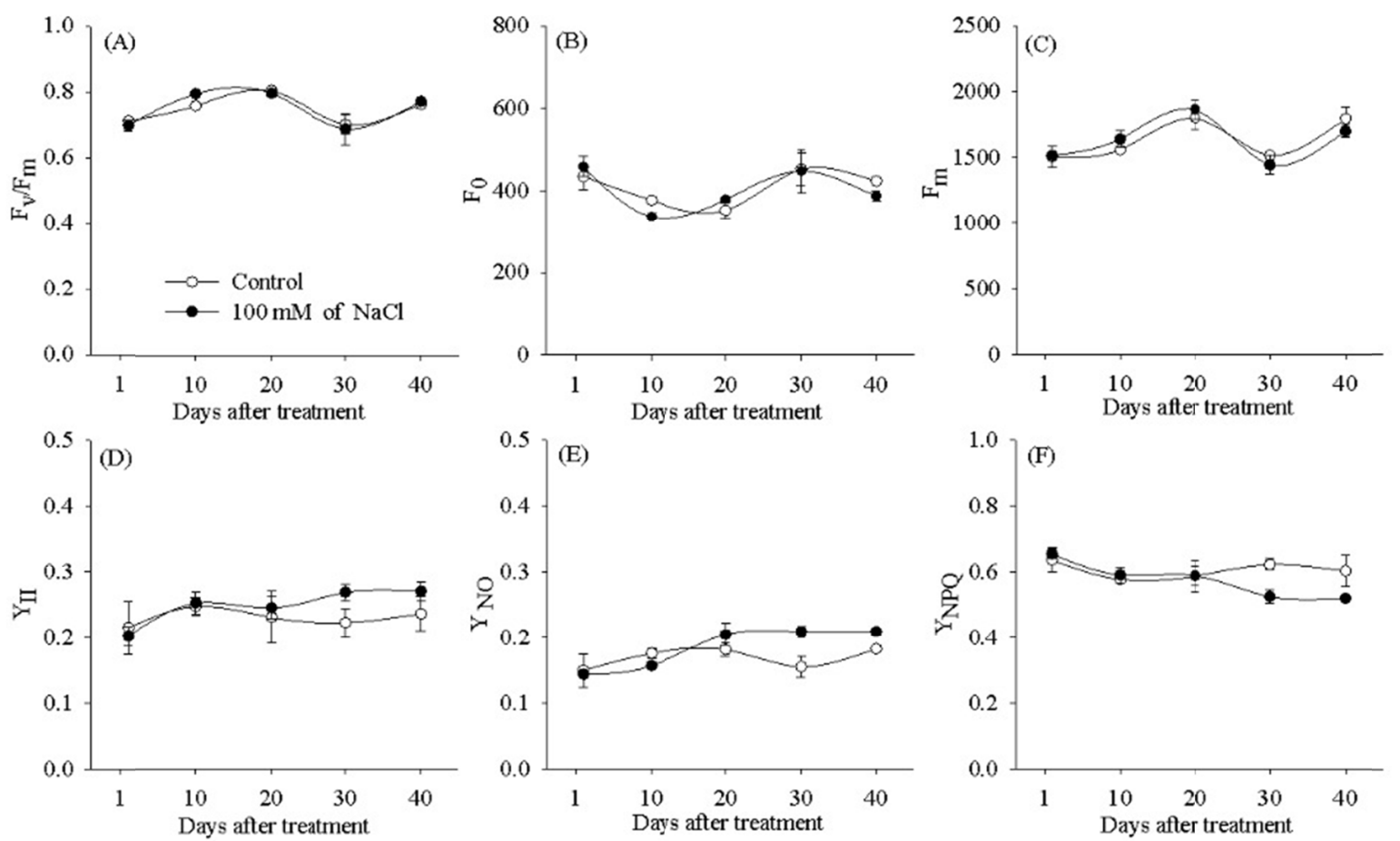

Figure 3. Potential quantum yield of PSII in oxidized state $-F_{v} / F_{m}(A)$; initial fluorescence $-F_{0}(B)$, maximum fluorescence $-F_{m}(C)$, effective quantum efficiency of PSII - $Y_{I I}(D)$, quantum yield of non-regulated dissipation $-\mathrm{Y}_{\mathrm{NO}}(\mathrm{E})$, quantum yield of regulated dissipation $-\mathrm{Y}_{\mathrm{NPQ}}(\mathrm{F})$ in noni plants grown for 40 days in hydroponic system in absence $(\circ)$ or presence $(\bullet)$ of $100 \mathrm{mM}$ of $\mathrm{NaCl}$ on nutrient solution. The values indicate the average of four repetitions and the vertical lines represent respective standard deviations 
$\mathrm{Y}_{\mathrm{NO}}$ is the light energy dissipated in a non-constitutive way by PSII antenna and can be associated to photoinhibition and other processes in the PSII reaction centers (Dos Anjos, Oliva, \& Kuki, 2012), especially when the PSII reaction centers are closed (Klughammer \& Schreiber, 2008). The results of present study show that salt stress increased $\mathrm{Y}_{\mathrm{NO}}$ at 30 and 40 days, indicating an increase of quenching in the form of heat during the transfer of excitation and fluorescence emission.

The quantum yield of regulated non-photochemical energy lost $\left(\mathrm{Y}_{\mathrm{NPQ}}\right)$ represents the light radiation excess which is dissipated as heat by the xanthophyll cycle (Klughammer \& Schreiber, 2008; Baraldi et al., 2008). The leaves of the stressed noni showed less $\mathrm{Y}_{\mathrm{NPQ}}$ compared to the control plants at 30 and 40 days. Among the different ways of energy dissipation evaluated, the observed increase of $\mathrm{Y}_{\mathrm{NO}}$ with the concomitantly decrease of $\mathrm{Y}_{\mathrm{NPQ}}$ indicate that the salinity decreased the photoprotection capacity of noni against the excessive radiation. Carotenoid content reduction in stressed plants from 30 days after treatment supports this hypothesis.

\subsection{Photosynthetic Pigments}

The salinity reduced the contents of all pigments in noni leaves (Figure 4). The $\mathrm{Chl} a, \mathrm{Chl} b$, and Chl tot contents decreased after 10 days of stress compared to control plants, and the Car contents decreased after 20 days (Figures 4A, 4B, 4C, and 4D). Thus, after 40 days of stress, reductions of, respectively $24,27,25$, and $17 \%$ for $\mathrm{Chl} a, \mathrm{Chl} b, \mathrm{Chl}$ tot, and Car contents were observed.

At 10 days of stress, the $\mathrm{Chl} a / \mathrm{Chl} b$ ratio increased by $16 \%$ (Figure $4 \mathrm{E}$ ) and $\mathrm{Chl}$ tot/Car ratio decreased by $34 \%$ (Figure 4F), compared to control plants. No differences were observed between the treatments in the other sampling times.

The pigment contents were reduced by salinity. Souto et al. (2015b) also reported reductions in the pigment contents of noni irrigated with saline water. The reduction of chlorophyll content in salt-stressed plants has been related to an inhibition in the chlorophyll biosynthesis (Taiz \& Zeiger, 2013), an increase in the chlorophyll degradation, or a decrease in the number of chloroplasts (Oliveira, Costa, \& Santos, 2013).
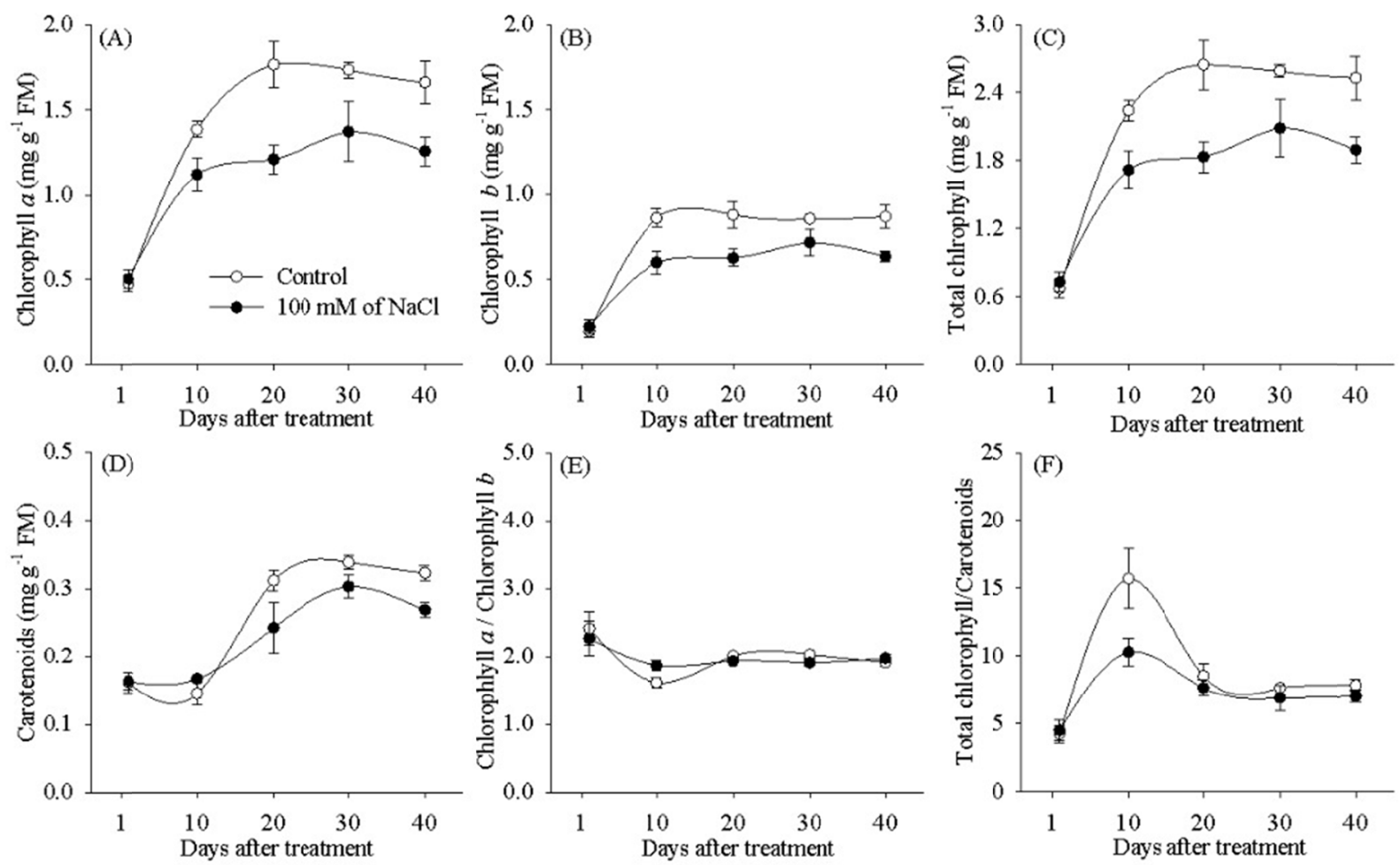

Figure 4. Contents of chlorophyll $a$ (A), chlorophyll $b$ (B), total chlorophyll (C), and carotenoids (D), and chlorophyll $a /$ chlorophyll $b$ (E) and total chlorophyll/carotenoids (F) ratios in noni plants grown for 40 days in hydroponic system in absence (O) or presence $(\bullet)$ of $100 \mathrm{mM}$ of $\mathrm{NaCl}$ on nutrient solution. The values indicate the average of four repetitions and the vertical lines represent respective standard deviations 
The reduction of chlorophyll content in noni plants grown under salt conditions reduces the photosynthetic activity (Souto et al., 2015b). Besides the chlorophylls, carotenoids are also integral components of the thylakoid membranes, and are normally associated with proteins that form the photosynthetic apparatus protecting the plants from damage caused by excessive light (Taiz \& Zeiger, 2013). In plants under stress, the carotenoids can also act as antioxidants protecting the lipids of thylakoid membranes from oxidative stress ( $\mathrm{Li}$, Wan, Zhou, Yang, \& Qin, 2010).

\subsection{Relative Water Content and Integrity of Cell Membranes}

Figure 5 shows the salt stress effects on the relative water content (RWC) and percentage of absolute integrity (PAI) of cell membranes of noni plants. The salinity did not affect the RWC during the experimental period (Figure 5A), but the PAI in stress treatment decreased by 40, 27, 20, and 17\% at 10, 20, 30, and 40 days after treatment, respectively (Figure 5B).

The salts in the plant rhizosphere induces osmotic stress and decreases the plant water uptake (Munns \& Tester, 2008). Thus, the relative water content (RWC) and the percentage of absolute integrity (PAI) of cell membranes are parameters related to the plant water status (Pimentel et al., 2002). In this study the salinity did not affect the RWC, but reduced PAI of membranes. Suárez (2011) reported that, in short-term, the ion accumulation provides an osmotic driving force for water uptake. The solute (organic and inorganic) accumulation is the mechanism responsible for the reduction of the cell water potential and maintenance of water uptake (Munns \& Tester, 2008). On the other hand, $\mathrm{Na}^{+}$and $\mathrm{Cl}^{-}$are toxic ions and their accumulation can cause serious damage to the plants (Munns \& Tester, 2008). In this study the data suggest an osmotic adjustment of salt-stressed noni plants, since the data of RWC have not indicated water deficit. The reduction of $g_{s}$ and $E$ in the plants under stress treatment indicates that the stomatal closure favored the maintenance of water status, which was evidenced by the maintenance of $W U E$.
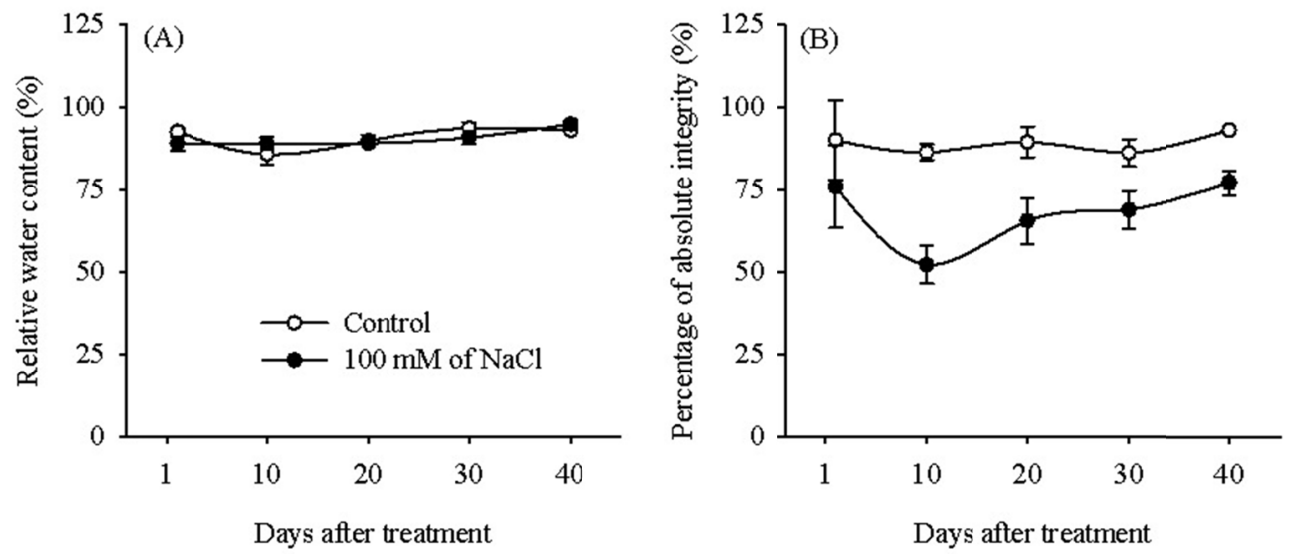

Figure 5. Relative water content (A) and percentage of absolute integrity of cell membrane (B) in noni plants grown during 40 days in hydroponic system in absence (O) or presence (•) of $100 \mathrm{mM}$ of $\mathrm{NaCl}$ on nutrient solution. The values indicate the average of four repetitions and the vertical lines represent respective standard deviations

The reduction in PAI of cell membranes evaluated by the electrolyte leakage was also observed in Brassica napus (Ashraf \& Ali, 2008) and Ananas porteanus (Mendes, Willadino, Cunha, Oliveira-Filho, \& Camara, 2011). irrigated with saline water According to Mendes et al. (2011), the reduction of PAI reflects the extent of lipid peroxidation caused by reactive oxygen species. Ashraf and Ali (2008) observed that the increase of PAI in salt-tolerant plants is related to increased activity of antioxidant enzymes.

\section{Conclusions}

Salinity affects the shoot dry mass production, the gas exchange, the pigments contents, and the membrane integrity in noni plants, but does not induce substantial changes in the chlorophyll $a$ fluorescence and relative water content. Salt stress also decreased the photoprotection capacity of noni leaves by the xanthophylls cycle. Data analysis suggests that noni presents as salt-tolerance mechanism the stomatal closure which reduces the water loss by transpiration and maintains the water status of the plant. 


\section{References}

Ashraf, M., \& Ali, Q. (2008). Relative membrane permeability and activities of some antioxidant enzymes as the key determinants of salt tolerance in canola (Brassica napus L.). Environmental and Experimental Botany, 63, 266-273. https://doi.org/10.1016/j.envexpbot.2007.11.008

Azevedo Neto, A. D., Perreira, P. P. A., Costa, D. P., \& Santos, A. C. C. (2011). Chlorophyll fluorescence as a possible tool for salt-stress tolerance screening in the sunflower. Revista Ciência Agronômica, 42, 893-897. https://doi.org/10.1590/S1806-66902011000400010

Baraldi, R., Canaccini, F., Cortes, S., Magnani, F., Rapparini, F., Zamboni, A., \& Raddi, S. (2008). Role of xanthophyll cycle-mediated photoprotection in Arbutus unedo plants exposed to water stress during the Mediterranean summer. Photosynthetica, 46, 378-386. https://doi.org/10.1007/s11099-008-0069-x

Barr, H. D., \& Weatherley, P. E. (1962). A re-examination of the relative turgidity technique for estimating water deficit in leaves. Australian Journal of Biological Science, 15, 413-428. https://doi.org/10.1071/BI9620413

Bezerra, A. K. P., Lacerda, C. F., Hernandez, F. F. F., Silva, F. B., \& Gheyi, H. R. (2010). Cowpea/corn crop rotation utilizing waters of different salinities. Ciência Rural, 40, 1075-1082. https://doi.org/10.1590/S0103 84782010000500012

Bezerra, M. A., Lacerda, C. F., Prisco, J. T., \& Gomes Filho, E. (2005). Growth and photosynthesis of young dwarf cashew plants grown under salt stress. Revista Brasileira de Engenharia Agrícola e Ambiental, 9, 90-94.

Brasil, Ministério da Integração Nacional, Câmara dos Deputados. (2007). Nova delimitação do Semiárido Brasileiro (p. 24). Estudo, Brasília, DF.

Chan-Blanco, Y., Vaillant, F., Perez, A. M., Reynes, M., Brillouet, J.-M., \& Brat, P. (2006). The noni fruit (Morinda citrifolia L.): A review of agricultural research, nutritional and therapeutic properties. Journal Food Composition Analysis, 19, 645-654. https://doi.org/10.1016/j.jfca.2005.10.001

Costa, A. B., Oliveira, A. M. C., Silva, A. M. O., Macini-Filho, J., \& Lima, A. (2013). Atividade antioxidante da polpa, casca e sementes do noni (Morinda citrifolia Linn). Revista Brasileira de Fruticultura, 35, $345-354$. https://doi.org/10.1590/S0100-29452013000200003

Critchley, C. (1998). Photoinhibition. In A. S. Raguavendra (Ed.), Photosynthesis: a comprehensive treatise (pp. 264-272). Cambridge: Cambridge University Press.

Dos Anjos, L., Oliva, M. A., \& Kuki, K. N. (2012). Fluorescence imaging of light acclimation of Brazilian Atlantic forest tree species. Photosynthetica, 50, 95-108. https://doi.org/10.1007/s11099-012-0018-6

Furlani, P. R. (1998). Instrução para o cultivo de hortaliça de folha pela técnica de hidroponia-NFT (Boletim Técnico, 168). Campinas: Instituto Agronômico.

Gonçalves, E. R., Ferreira, V. M., Silva, J. V., Endes, L., Barbosa, T. P., \& Duarte, W. G. (2010). Gas exchange and chlorophyll a fluorescence of sugarcane varieties submitted to water stress. Revista Brasileira de Engenharia Agrícola e Ambiental, 14, 378-386. https://doi.org/10.1590/S1415-4366201000 0400006

Iqbal, N., Umar, S., Khan, N. A., \& Khan, M. R. (2014). A new perspective of phytohormones in salinity tolerance: Regulation of proline metabolism. Environmental and Experimental Botany, 100(1), 34-42. https://doi.org/10.1016/j. envexpbot.2013.12.006

Kalaji, H. M., Oukarroum, A., Alexandrov, V., Kouzmanova, M., Brestic, M., Zivcak, M., ... Goltsev, V. (2014). Identification of nutrient deficiency in maize and tomato plants by in vivo chlorophyll $a$ fluorescence measurements. Plant Physiology and Biochemistry, 81, 16-25. https://doi.org/10.1016/j.plaphy.2014.03.029

Klughammer, C., \& Schreiber, U. (2008). Complementary PSII quantum yield calculated from simple fluorescence parameters measured by PAM fluorometry and saturation pulse method. PAM Application Notes, 1(1), 27-35. Retrieved from http://www.walz.com/downloads/pan/PAN11001.pdf

Kramer, D. M., Johnson, G., Kiirats, O., \& Edwards, G. E. (2004). New fluorescence parameters for the determination of QA redox stat and excitation energy fluxes. Photosynthesis Research, 79, 209-218. https://doi.org/10.1023/B:PRES.0000015391.99477.0d

Li, G., Wan, S., Zhou, J., Yang, Z., \& Qin, P. (2010). Leaf chlorophyll fluorescence, hyperspectral reflectance, pigments content, malondialdehyde and proline accumulation responses of castor bean (Ricinus communis 
L.) seedlings to salt stress levels. Industrial Crop Production, 31, 13-19. https://doi.org/10.1016/j.indcrop. 2009.07.015

Lichtenthaler, H. K., \& Buschmann, C. (2001). Chlorophylls and carotenoids: measurement and characterization by UV-VIS spectroscopy. Current Protocols in Food Analytical Chemistry, F4.3.1-F4.3.8. https://doi.org/ 10.1002/0471142913.faf0403s01

Machado, E. C., Schmidt, P. T., Medina, C. L., \& Ribeiro, R. V. (2005). Photosynthetic responses of three citrus species to environmental factors. Pesquisa Agropecuária Brasileira, 40, 1161-1170, https://doi.org/10.1590/ S0 100-204X2005001200002

Mendes, B. S. S., Willadino, L., Cunha, P. C., Oliveira-Filho, R. A., \& Camara, T. R. (2011). Physiological and biochemical mechanisms of ornamental pineapple under salt stress. Revista Caatinga, 24(3), 71-77. Retrieved from http://periodicos.ufersa. edu.br/revistas/index.php/sistema/article/view/1956

Munns, R., \& Tester, M. (2008). Mecanisms of salinity tolerance. Annual Review of Plant Biology, 59, 651-681, https://doi.org/10.1146/annurev. arplant.59.032607.092911

Nelson, S. C., \& Elevitch, C. R. (2006). Workshop manual to supplement noni: The complete guide for consumers and growers for noni processing, marketing, and field training workshop for YAP (pp. 1-18). Holualoa, Hawaii: Permanent Agriculture Resources.

Oliveira, H., Costa, A., \& Santos, C. (2013). NaCl and Phaeomoniella chlamydospora affect differently starch and sucrose metabolism in grapevines. Acta Scientiarum Agronomy, 35(2), 153-159. https://doi.org/ 10.4025/actasciagron.v35i2.15690

Peña-Olmos, J. E., \& Casierra-Posada, F. (2013). Chlorophyll fluorescence in partially defoliated grape plants (Vitis vinifera L. cv. chardonnay). Revista Facultad Nacional Agronomía, 66, 6881-6889. Retrieved from http://www.redalyc.org/html/1799/179928411005/index.html

Pimentel, C., Sarr, B., Diouf, O., Abboud, A. C. S., \& Roy-Maculey, H. (2002). Tolerância protoplasmática foliar à seca, em dois genótipos de caupi cultivadas em campo. Revista Universidade Rural, 22(1), 07-14. Retrieved from http://www.editora.ufrrj.br/rcv2/rcv22n1/07-14.pdf

Praxedes, S. C., Lacerda, C. F., Damatta, F. M., Prisco, J. T., \& Gomes-Filho, E. (2010). Salt tolerance is associated with differences in ion accumulation, biomass allocation and photosynthesis in cowpea cultivars. Journal of Agronomy and Crop Science, 196, 193-204. https://doi.org/10.1111/j.1439-037X.2009.00412.x

Rodrigues, C. R. F., Silva, E. N., Moura, R. M., Anjos, D. C., Hernandez, F. F. F., \& Viégas, R. A. (2014). Physiological adjustment to salt stress in R. communis seedlings is associated with a probable mechanism of osmotic adjustment and a reduction in water lost by transpiration. Industrial Crops Production, 54, 233-239. https://doi.org/10.1016/j.indcrop.2013.12.041

Rohàček, K., \& Barták, M. (1999). Technique of the modulated chlorophyll fluorescence: Basic concepts, useful parameters, and some applications. Photosynthetica, 37, 339-363. https://doi.org/10.1023/A:10071724 24619

Silva, E. N., Ribeiro, R. V., Ferreira-Silva, S. L., Viégas, R. A., \& Silveira, J. A. G. (2011). Salt stress induced damages on the photosynthesis of physic nut young plants. Scientia Agricola, 68(1), 62-68. https://doi.org/ 10.1590/S0103-90162011000100010

Silva, L. A., Brito, M. E. B., Sá, F. V. S., Moreira, R. C. L., Soares Filho, W. S., \& Fernandes, P. D. (2014). Mecanismos fisiológicos em híbridos de citros sob estresse salino em cultivo hidropônico. Revista Brasileira de Engenharia Agrícola e Ambiental, 18, 1-7. https://doi.org/10.1590/1807-1929/agriambi.v18 nsupps 1-s7

Silva, M. A., Jifon, J. L., Santos, C. M., Jadoski, C. J., \& Silva, J. A. G. (2013). Photosynthetic capacity and water use efficiency in sugarcane genotypes subject to water deficit during early growth phase. Brazilian Archives of Biology and Technology, 56, 735-748. https://doi.org/10.1590/S1516-89132013000500004

Snedecor, G. W. (1956). Statistical methods applied to experiments in agriculture and biology (p. 534). Ames: The Iowa State College Press.

Souto, A. G. L., Cavalcante, L. F., Diniz, B. L. M. T., Mesquita, F. O., Nascimento, J. A. M., \& Lima Neto, A. J. (2015a). Saline water and bovine biofertilizer on yield and biomass allocation in noni plant (Morinda citrifolia L.). Revista Brasileira de Plantas Medicinais, 17, 340-348. https://doi.org/10.1590/1983-084 $\mathrm{X} / 13$ - 03 
Souto, A. G. L., Cavalcante, L. F., Gheyi, H. R., Nunes, J. C., Oliveira, F. I. F., \& Oresca, D. (2015b). Photosynthetic pigments and biomass in noni irrigated with saline waters with and without leaching. Revista Brasileira de Engenharia Agrícola, 19(11), 1042-1048. https://doi.org/10.1590/1807-1929/agriambi.v19n11 p1042-1048

Souto, A. G. L., Cavalcante, L. F., Lima Neto, A. J., Mesquita, F. O., \& Santos, J. B. (2016). Biometrics in noni plants under irrigation with saline water and the leaching of salts from the soil. Revista Ciência Agronômica, 47, 316-324. https://doi.org/10.5935/1806-6690.20160037

Souza, M. C. M., Lacerda, C. F., Amorim, A. V., \& Menezes, A. S. (2014). Influence of organic matter and the environment in growth and in solute accumulation in Morinda citrifolia submitted to salinity. Revista Brasileira de Fruticultura, 36, 704-712. https://doi.org/10.1590/0100-2945-319/13

Suárez, N. (2011). Effects of short-and long-term salinity on leaf water relations, gas exchange, and growth in Ipomoea pes-caprae. Flora, 206, 267-275. https://doi.org/10.1016/j.flora.2010.05.006

Taiz, L., \& Zeiger, E. (2013). Fisiologia vegetal (p. 918). Porto Alegre: Artmed.

Viana, S. B. A., Fernandes, N. P. D., Gheyi, H. R., Soares, F. A. L., \& Carneiro, P. T. (2004). Morphophysiological indices and production of lettuce under saline stress. Revista Brasileira de Engenharia Agrícola e Ambiental, 8(1), 23-30. https://doi.org/10.1590/S1415-43662004000100004

Wang, H., Wang, F. L., Wang, G., \& Majourhat, K. (2007). The responses of photosynthetic capacity, chlorophyll fluorescence and chlorophyll content of nectarine (Prunus persica var. nectarina maxim) to greenhouse and field grown conditions. Scientia Horticulturae, 112, 66-72. https://doi.org/10.1016/j.scienta.2006.12.007

\section{Copyrights}

Copyright for this article is retained by the author(s), with first publication rights granted to the journal.

This is an open-access article distributed under the terms and conditions of the Creative Commons Attribution license (http://creativecommons.org/licenses/by/4.0/). 